\title{
Questionnaire to evaluate COVID-19 suspected patient before the dental procedure.
}

Dr. Md. Ashif lqbal ${ }^{1 *}$

\begin{abstract}
AFFILIATION:
1. Dr. Md. Ashif Iqbal

Associate Professor \& Head

Dept. of Periodontology \& Oral pathology

Update Dental College \& Hospital
\end{abstract}

\section{Article info.}

Received: $24^{\text {th }}$ March 2020

Accepted: $26^{\text {th }}$ March 2020

Volume: 10, Issue-1 April, 2020

DOI: https://doi.org/10.3329/updcj.v10i1.46683

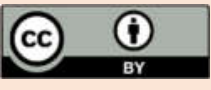

(C) Authors retain copyright and grant the journal right of first publication with the work simultaneously licensed under Creative Commons Attribution License CC - BY 4.0 that allows others to share the work with an acknowledgment of the work's authorship and initial publication in this journal.

https://creativecommons.org/licenses/by/4.0/

Publisher: Update Dental College, Dhaka, Bangladesh

Web: www.updatedentalcollege.edu.bd

E-mail: updcj@hotmail.com

* Corresponding Author Dr. Md. Ashif Iqbal Associate Professor \& Head

Dept. of Periodontology \& Oral pathology

Update Dental College \& Hospital Cell: +8801716116080

E-mail: drasif100@gmail.com

ORCID Id: http://orcid.org/0000-0002-9490-7927

\section{INTRODUCTION:}

Healthcare professionals have been immediately involved in the national emergency \& working hard, often day and night. It is very pathetic that unfortunately, some of them have also become infected, and some have lost their life. Dentists are usually the first line of diagnosis, as they work in close contact with patients. On 15 March 2020, the New York Times published an article with the title "The Workers Who Face the Greatest Coronavirus Risk", where an impressive schematic figure described that dentists are the workers most exposed to the risk of being affected by COVID-19, much more than nurses and general physicians ${ }^{1}$. Therefore, for this, a dentist should take precautions before delivering the treatment. American Dental Association (ADA) has given a guideline regarding treatment protocol during this critical situation. https://www.ada.org/en/press-room/news-releases/2020archives/april/summary-of-ada-guidance-during-the-covid19-crisis?, FDI World Dental Federation, also have published a guideline for an oral professional during this COVID-19 outbreak. https://www. fdiworlddental.org/covid-19outbreak-guidance-for-oral-health-professionals. Before consultation or service provided by the oral health professional, Patient evaluation by structural questionnaire may help a dentist to prevent contamination and early detection of COVID-19 patients.

\section{STRUCTURAL QUESTIONNAIRE:}

A Dental professional could be able to identify a suspected case of COVID-19. In general, a patient with COVID-19 who is in the acute febrile phase of the disease is not recommended to visit the dental clinic. If this does occur, the dental professional should be able to identify the patient with suspected COVID-19 infection, and should not treat the patient in the dental clinic, but immediately quarantine the patient and report to the infection control department as soon as possible, particularly in the epidemic period.

The temperature of the patient should be measured first. A contact-free forehead thermometer is strongly recommended for the screening. A questionnaire asking by one of a health professional to prevent contamination from a patient should be taken secondly. The following questionnaire could be used to screen patients before they could be led to dental treatment. According to Peng $X$ et all, These questions should include the following: "(1) Do you have fever or experience fever within the past 14 days? (2) Have you experienced a recent onset of respiratory problems, such as a cough or 
difficulty in breathing within the past 14 days? (3) Have you, within the past 14 days, traveled to Wuhan city and its surrounding areas, or visited the neighborhood with documented 2019-nCoV transmission? (4) Have you come into contact with a patient with confirmed 2019-nCoV infection within the past 14 days? (5) Have you come into contact with people who come from Wuhan city and its surrounding areas, or people from the neighborhood with recently documented fever or respiratory problems within the past 14 days? (6) Are there at least two people with documented experience of fever or respiratory problems within the last 14 days having close contact with you? (7) Have you recently participated in any gathering, meetings, or had close contact with many unacquainted people?"2 (8) As the COVID-19 has now been an outbreak in different countries globally according to WHO data, That's why any Travel history within last 14 days should include in the questionnaire.

According to Peng $X$ et al, He has mentioned in his article that "If a patient replies "yes" to any of the screening questions, and his/her body temperature is below $37.3^{\circ} \mathrm{C}$, the dentist can defer the treatment until 14 days after the exposure event. The patient should be instructed to self-quarantine at home and report any fever experience or flu-like syndrome to the local health department. If a patient replies "yes" to any of the screening questions, and his/her body temperature is no less than $37.3^{\circ} \mathrm{C}$, the patient should be immediately quarantined, and the dental professionals should report to the infection control department of the hospital or the local health department. If a patient replies "no" to all the screening questions, and his/her body temperature is below $37.3^{\circ} \mathrm{C}$, the dentist can treat the patient with extra- protection measures and avoids spatter or aerosol-generating procedures to the best. If a patient replies "no" to all the screening questions, but his/her body temperature is no less than $37.3^{\circ} \mathrm{C}$, the patient should be instructed to the fever clinics or special clinics for COVID-19 for further medical care" 2

According to Spagnuolo $G$ et al, The most recommended guidelines suggest that dentists should avoid the scheduling of any patient despite emergency dental diseases that can be considered during the COVID-19 outbreak. This action could limit the interpersonal contact, the waiting time of patients in dental cabinets and, in general, the conditions predisposing patients to be infected. ${ }^{3}$

\section{CONCLUSION:}

Questionnaires may help to detect any suspected case primarily. But it is not confirmatory even some patients could indeed hide the information's due to different psychological factors and professional has a chance to become infected. For this, a policy should be developed to give a message to all patients through different media regarding the harmful impact and its consequences to hide the information to the health care professional.

\section{REFERENCES:}

1. Gamio L. The Workers Who Face the Greatest Coronavirus Risk. [(accessed on 15 March 2020)]; Available online: https://www.nytimes.com/interactive/2020/03/15/busin ess/economy/coronavirus-worker-

risk.html?action=click\&module=Top+Stories\&pgtype=Ho mepage.

2. Peng $X, X u X$, Li $Y$, Cheng L, Zhou X, Ren B. Transmission routes of 2019-nCoV and controls in dental practice. Int J Oral Sci. 2020;12(1):9. Published 2020 Mar 3. DOI:10.1038/s41368-020-0075-9 https://doi.org/10.1038/s41368-020-0075-9

PMid:32127517 PMCid:PMC7054527

3. Spagnuolo G, De Vito D, Rengo S, Tatullo M. COVID-19 Outbreak: An Overview on Dentistry. Int J Environ Res Public Health. 2020;17(6):2094. Published 2020 Mar 22. DOI:10.3390/ijerph17062094 https://doi.org/10.3390/ijerph17062094 PMid:32235685 PMCid:PMC7143628 